\title{
Patient Motion Artifact
}

National Cancer Institute

\section{Source}

National Cancer Institute. Patient Motion Artifact. NCI Thesaurus. Code C87038.

An artifact resulting from movement of the patient during image capture. 